\title{
The Effect of Niobium Addition and Heat Treatment on the Phase Structure of Fe3Al - Type Intermetallic Alloys
}

\section{Martin Švec, Věra Vodičková}

Department of Material Science, Technical University of Liberec, Studentská 2, 46117 Liberec 1, Czech Republic, martin.svec@tul.cz

The iron aluminides seem to be a promising materials for high-temperature applications. They have a wide range of positive properties, but unfortunately also some negative (for example low ductility at room temperature or sharp drop in strength above $600^{\circ} \mathrm{C}$ ). The addition of third element into the alloy can be the way to improvement of the properties. $\mathrm{Nb}, \mathrm{Zr}$ or Ta seem to be appropriate elements. The niobium addition to the Fe-Al matrix leads to the formation of Laves phase. If the Laves phase is presented in an appropriate shape, it could enhance high temperature mechanical properties. These properties are dependent on the structure of alloy - mainly on second phase distribution and type.Two alloys with different content of niobium were investigated. The influence of niobium content and heat treatment on the structure and mechanical properties of the alloys were studied. The phase composition was determined using scanning electron microscopy (SEM) equipped by energy dispersive analysis (EDX) and electron backscattered diffraction detector (EBSD). This paper is the first part of study and it deals with description of the alloy structure and phases in the investigated materials.

Keywords: $\mathrm{Fe} 3 \mathrm{Al}$ - type iron aluminides, $\mathrm{Nb}$ addition, phase structure, heat treatment

\section{Acknowledgment}

This research was supported by Grant Agency of the Czech Republic through the Project No. P108/12/1452.

\section{References}

[1] MC KAMEY, C. G. (1994) Iron Aluminides. In Physical Metalurgy and processing of Intermetallic Compounds, eds. STOLOFF N. S. - SIKKA V. K., $351-391$.

[2] STOLOFF, N. S. (1998) Iron aluminides: present status and future prospects. In Materials Science and Engineering A258. 1 - 14.

[3] DEEVI, S. C., SIKKA, V. K. (1996) Nickel and iron aluminides: an overview on properties, processing and applications. In Intermetallics 4. 357 - 375.

[4] PALM, M. (2005) Concepts derived from phase diagram studies for the strengthening of Fe - Al-based alloys. In Intermetallics 13. $1286-1295$.

[5] PALM, M., SCHNEIDER, A., STEIN, F., SAUTHOFF, G. (2005) Strengthening of iron aluminide alloys for hightemperature applications. In Mater. Res. Soc. Symp. Proc. Vol. 842. S1.7.1 - S1.7.12.

[6] KRATOCHVÍL, P., KEJZLAR, P., KRÁL, R., VODIČKOVÁ, V. (2012) The effect of Zr addition on the structure and high temperature strength of Fe-30 at. \% Al type alloys. In Intermetallics 20. $39-46$

[7] MORRIS, D. G. A et al. (2006) Strengthening at high temperatures by precipitates in Fe-Al-Nb alloys. In Intermetallics 14. $1204-1207$

[8] DIMIDUK, D. M., MENDIRATTA, M. G., BANERJEE, D., LIPSITT, H. A. (1988) A structural study of ordered precipitates in an ordered matrix within the Fe-Al-Nb system. In Acta Metallurgica, Vol. 36, Issue 11. 2947 - 2958.

[9] RISANTI, D. D., SAUTHOFF, G. (2005) Strengthening of iron aluminide alloys by atomic ordering and Laves phase precipitation for high-temperature applications. In Intermetallics 13. $1313-1321$.

[10] HANUS, P. et al. (2010) Mechanical properties of a forged Fe-25Al-2Ta steam turbine blade. In Intermetallics 18. $1379-1384$.

[11] RISANTI, D. D., SAUTHOFF, G. (2011) Microstructures and mechanical properties of Fe-Al-Ta alloys with strengthening Laves phase. In Intermetallics 19. 1727 - 1736.

[12] MORRIS, D. G., REQUEJO, L. M., MUNOZ - MORRIS, M. A. (2005) A study of precipitation in D03 ordered Fe-Al-Nb alloy. In Intermetallics 13. $862-871$. 
[13] EFFENBERG, G., ILYENKO, S. - Editors (2009) Ternary alloy systems. Springer publishing: Berlin. ISBN 9783-540-88052-3.

[14] ALONSO, P. R. et al. (2001) Combined ab intio and experimental study of A2 + L21 coherent equilibria in the Fe-Al-X (X=Ti, Nb, V) systems. In Intermetallics 19. $1157-1167$.

[15] VILLARS, P. et al. (1995) Handbook of ternary Alloy Phase Diagrams. 1. edition. ASM International Publishing. Volume 3 (Ag-Al-As - Al-Ga-Gd). ISBN 0-87170-525-7.

[16] RAGHAVAN, V. (2010) Al-Fe-Nb (Aluminium-Iron-Niobium). In Journal of Phase Equilibria and Diffusion, Vol. 31, No. 2. $166-167$.

[17] PALM, M. Unpublished results.

[18] ŠVEC, M. (2014) Unpublished research, Technical University of Liberec.

\section{Paper number: M201485}

Copyright $($ C 2014. Published by Manufacturing Technology. All rights reserved. 